\title{
Pengaruh Model Pembelajaran Cooperative Learning Tipe Course Review Horay Terhadap Motivasi dan Hasil Belajar Tematik Pada Peserta Didik SD Inpres Bakung II Kota Makassar
}

\section{The Effect of Cooperative Learning Model Type Course-Review-Horay on Motivation and Thematic Learning Outcomes of Students in SD Inpres Bakung II, Makassar City}

\author{
Kurniati ${ }^{1}$, Muhammad Yunus ${ }^{2}$, Muhammad Nur² \\ ${ }^{1}$ Dinas Pendidikan Kota Makassar, Sulawesi Selatan \\ ${ }^{2}$ Program Studi Studi Pendidikan Dasar, Program Pascasarjana, Universitas Bosowa \\ E-mail: kurniatipgsd2017@gmail.com
}

Diterima: 14 Juli 2020/Disetujui 07 Desember 2020

\begin{abstract}
Abstrak. Proses pendidikan bertujuan untuk menghasilkan peserta didik mengalami peningkatan kemampuan akademik secara kuantitatif dan memiliki motivasi untuk belajar tinggi. Kedua hal ini sangat dipengaruhi oleh metode yang digunakan oleh guru dalam proses pembelajaran. Course Review Horay merupakan salah satu metode yang diyakini dapat meningkatkan kemampuan akademik dan motivasi belajar pada anak karena dapat meningkatkan pemahaman anak dan menghasilkan suasana belajar yang menyenangkan. Jenis penelitian adalah Quasi Experimental Design dengan rancangan NonEquivalent Control Group Design. Penelitian ini dilaksanakan di SD Inpres Bakung II Kota Makassar. Populasi penelitian ini adalah seluruh peserta didik kelas V yang berjumlah 78 peserta didik. Sampel penelitian ini terdiri dari 40 peserta didik kelas V-A dan 38 peserta didik kelas V-B. Penentuan kelompok eksperimen dan kelompok kontrol dilakukan dengan teknik purposive sampling uji hipotesis yang digunakan adalah uji Wilcoxon. Hasil penelitian menunjukkan bahwa; (1) Model pembelajaran Course Review Horay dapat meningkatkan motivasi peserta didik dalam pembelajaran, (2) Model pembelajaran Course Review Horay dapat meningkatkan hasil belajar peserta didik, (3) Terdapat pengaruh penerapan model pembelajaran Course Review Horay terhadap motivasi belajar peserta didik. Dan (4) Terdapat pengaruh penerapan model pembelajaran Course Review Horay terhadap hasil belajar peserta didik.
\end{abstract}

Kata Kunci: Course Review Hooray, Motivasi Belajar, Prestasi Belajar, Makassar

\begin{abstract}
Education aims to improve academic abilities and learning motivation of students. Both of these are highly influenced by the method used by teachers in learning process. Course-Review-Horay is one method that is believed to improve academic ability and learning motivation of children because it can increase children's understanding and generate a fun learning environment. This type of research is Quasi Experimental Design with NonEquivalent Control Group Design. This research was conducted at SD Inpres Bakung II Makassar City. The population of this study were all grade V students, counting for 78 students. The sample of this study consisted of 40 students in class $V$-A and 38 students in calss $V$ - $B$. The decision of the experimental group and the control group was done by using purposive sampling. Hypothesis test used was Wilcoxon test. The results show that; (1) Course-Review-Horay learning model can increase student motivation in learning, (2) Course-Review-Horay learning model can improve student learning outcomes, (3) There is an influence of the implementation of Course-Review-Horay learning model to students' learning motivation, and (4) There is an influence of the implementation of Course-Review-Horay learning model to students' learning achievement.
\end{abstract}

Keywords: Course-Review-Hooray, Learning Motivation, Learning Achievement, Makassar

\section{Pendahuluan}

Kemajuan suatu negara sangat ditentukan oleh kualitas sumber daya manusia, sedangkan kualitas sumber daya manusia sangat ditentukan oleh kualitas pendidikannya. Peran pendidikan sangat penting dalam menciptakan masyarakat yang cerdas, religius, mandiri, terbuka, dan demokratis. Tinggi rendahnya martabat suatu bangsa sangat ditentukan oleh pendidikan masyarakatnya. Oleh karenanya pemerintah terus berupaya untuk meningkatkan kualitas pendidikan demi mencerdaskan kehidupan bangsa.

Sebagaimana tercantum dalam Undang-Undang No.20 Tahun 2003 Bab II pasal 3: Pendidikan Nasional berfungsi mengembangkan kemampuan dan membentuk watak peradaban bangsa yang bermartabat dalam rangka mencerdaskan kehidupan bangsa, bertujuan untuk berkembangnya potensi peserta didik agar menjadi manusia yang beriman dan bertaqwa kepada Tuhan Yang Maha Esa, berakhlak mulia, sehat, berilmu, cakap, kreatif, mandiri, dan menjadi warga negara yang demokratis serta bertanggung jawab. 
Berdasarkan isi Undang-Undang No.20 Tahun 2003 tentang Sistem Pendidikan Nasional pada Bab II pasal 3 bahwa melalui pendidikan seseorang dapat mengembangkan kualitas pribadinya sesuai dengan minat dan bakatnya. Hal ini tentu akan meningkatkan sumber daya manusia yang ada. Secara bertahap pemerintah terus berusaha meningkatkan pendidikan di setiap jenjang pendidikan dimulai dari pendidikan dasar, pendidikan menengah, dan pendidikan tinggi. Sebagaimana ditetapkan dalam pasal 13 Undang-Undang nomor 2 tahun 1989 bahwa Pendidikan Dasar diselenggarakan untuk mengembangkan sikap dan memberikan kemampuan serta memberikan pengetahuan dan keterampilan dasar yang diperlukan untuk hidup di dalam masyarakat serta mempersiapkan peserta didik yang memenuhi persyaratan untuk mengikuti pendidikan menengah. Keberadaan Sekolah Dasar atau Madrasah Ibtidaiyah menjadi bagian dari pelaksanaan program wajib belajar 9 tahun.

Pelaksanaan pendidikan pada jenjang SD/MI mengacu pada kurikulum yang berlaku. Kurikulum yang digunakan di SD tempat penelitian adalah kurikulum 2013. Kurikulum 2013 untuk sekolah dasar adalah tematik integratif yang menyuguhkan proses belajar berdasarkan tema untuk kemudian dikombinasikan dengan mata pelajaran lainnya. Dalam kurikulum 2013, mata pelajaran yang diajarkan ada 7 mata pelajaran, diantaranya: Pendidikan Agama, Bahasa Indonesia, PPKn, Matematika, Kesenian, pendidikan Jasmani dan Olah Raga Kesehatan, dan Pengetahuan umum.

Namun fakta di lapangan ditemukan bahwa pelaksanaan pembelajaran tematik di Sekolah Dasar yang diterapkan masih kurang optimal. Peneliti menemukan bahwa peserta didik kurang memperhatikan saat guru menjelaskan pelajaran, peserta didik kurang aktif bertanya, dan menjawab pertanyaan. Selain itu, guru lebih banyak mendominasi kegiatan pembelajaran dan belum melibatkan peserta didik belajar secara berkelompok. Guru belum maksimal dalam melakukan pendekatan pembelajaran yang sesuai sehingga pembelajaran terkesan kaku, dan membosankan.

Hal tersebut juga didikung oleh penelitian yang dilakukan oleh Erna Mustika, 2015, dengan judul "Peningkatan Kualitas Pembelajaran PKn Melalui Pembelajaran Cooperatif Course Review Horay dengan Media Diorama Pada Siswa Kelas V SD Negeri Barukan 02 Semarang”. Begitu pula penelitian yang dilakukan oleh Anita Yulia Firdiana, 2016. Dengan judul "Pengaruh Metode Pembelajaran Course Review Horay (CRH) Terhadap Aktivitas Dan Hasil Belajar IPS Kelas V Di SDN Gugus Puspita Jepara. Dan masih banyak lagi penelitian yang telah di lakukan yang sehubungan dengan model Pembelajaran Course Review Horay . Dengan adanya perbaikan pembelajaran, keterampilan guru dalam pembelajaran mengalami peningkatan. Pembelajaran lebih berpusat pada peserta didik dan guru berperan sebagai pembimbing, fasilitator, dan dinamisator dalam pembelajaran. Motivasi dan hasil belajar peserta didik mengalami peningkatan. Dengan demikian data dari hasil penelitian tersebut oleh peneliti dapat dijadikan sebagai pendukung, karena model pembelajaran Course Review Horay ini menurut Shoimin (2014) dapat meningkatkan semangat belajar sebab suasana pembelajaran berlangsung menyenangkan. Dapat disimpulkan bahwa kualitas pembelajaran mengalami peningkatan.

Model pembelajaran Course Review Horay bukanlah hal baru karena pendekatan pembelajaran ini sudah berkembang di kalangan guru-guru terutama di pulau Sumatera dan Jawa. Namun di pulau Sulawesi khususnya di Kota Makassar, model pembelajaran Course Review Horay masih jarang digunakan. Untuk itulah pendekatan pembelajaran ini, akan peneliti perkenalkan sehingga dalam menggunakan model pembelajaran lebih bervariasi.

Model pembelajaran Course Review Horay merupakan suatu metode pembelajaran dengan pengujian pemahaman menggunakan kotak yang di isi dengan nomor untuk menuliskan jawabannya, yang paling lebih dulu mendapatkan tanda benar vertical dan horizontal, atau diagonal langsung berteriak horee!!. Metode pembelajaran ini dapat meningkatkan semangat belajar peserta didik di kelas dan menghilangkan rasa tertekan peserta didik saat mengerjakan tugas yang diberikan oleh guru. Karena pemeriksaan tugas yang diberikan guru, benar jika para peserta didik berteriak horee !!.

Penggunaan model pembelajaran Course Review Horay memotivasi peserta didik untuk aktif dalam pembelajaran tematik. Model pembelajaran ini lebih menekankan pada pemahaman materi yang di ajarkan guru dengan menjawab soalsoal. Model pembelajaran Course Review Horay tidak hanya meningkatkan prestasi akademik peserta didik saja. Melainkan juga dapat mengembangkan keterampilan bekerja sama dalam suatu kelompok, melatih kejujuran dan lebih bertanggung jawab. Model pembelajaran Course Review Horay merupakan pembelajaran yang berpusat pada peserta didik yang dikemas dalam bentuk permainan. Suasana belajar menjadi lebih menyenangkan, pembelajaran menjadi lebih bermakna dan di harapkan peserta didik lebih bersemangat mengikuti proses pembelajaran.

Menurut Sagala dalam Faturrohman (2017), istilah model dapat dipahami sebagai suatu kerangka konseptual yang digunakan sebagai pedoman dalam melakukan suatu kegiatan. Model dapat juga dipahami sebagai: (1) suatu tipe atau desain; (2) suatu deskripsi atau analogi yang dipergunakan untuk membantu proses visualisasi sesuatu yang tidak dapat dengan langsung diamati; (3) suatu sistem asumsi-asumsi, data-data, dan inferensi-inferensi yang digunakan menggambarkan secara sistematis suatu objek atau peristiwa; (4) suatu desain yang disederhanakan dari suatu sistem kerja, suatu terjemahan realitas yang disederhanakan; (5) suatu deskripsi dari suatu sistem yang mungkin atau imajiner; dan (6) penyajian yang diperkecil agar dapat menjelaskan dan menunjukkan sifat bentuk aslinya. Model dirancang untuk mewakili realitas yang sesungguhnya walaupun model itu sendiri bukanlah realitas dari dunia yang sebenarnya. Oleh karena itu, model pembelajaran adalah kerangka konseptual yang digunakan sebagai pedoman dalam melakukan kegiatan pembelajaran. Secara konkret, dapat dikemukakan bahwa model pembelajaran adalah kerangka konseptual yang mendeskripsikan dan melukiskan prosedur yang sistematik dalam mengorganisasikan pengalaman belajar dan pembelajaran untuk mencapai tujuan belajar tertentu dan berfungsi sebagai pedoman dalam perencanaan pembelajaran bagi para pendidik dalam melaksanakan aktivitas pembelajaran.

Menurut Soekamto dalam shoimin (2014), mengemukakan maksud dari model pembelajaran adalah kerangka konseptual yang melukiskan prosedur yang sistematis dalam mengorganisasikan pengalaman belajar untuk mencapai tujuan belajar tertentu. Komalasari (2015) mengemukakan bahwa model pembelajaran pada dasarnya merupakan bentuk pembelajaran yang tergambar dari awal sampai akhir yang disajikan secara khas oleh guru.

Menurut Joyce \& Well dalam Rusman (2016) Mendefinisikan model pembelajaran sebagai suatu perencanaan atau suatu pola yang digunakan sebagai pedoman dalam melaksanakan pembelajaran di kelas atau pembelajaran dalam tutorial 
dan untuk menemukan perangkat-perangkat pembelajaran. Model pembelajaran adalah suatu perencanaan atau suatu pola yang digunakan sebagai pedoman dalam merencanakan pembelajaran di kelas atau pembelajaran dalam tutorial (Trianto, 2015).

Berdasarkan beberapa pengertian yang telah dikemukakan oleh para ahli diatas, dapat disimpulkan bahwa model pembelajaran adalah kerangka konseptual yang melukiskan rencana pembelajaran dari awal sampai akhir berisi prosedur yang tersusun secara sistematis dalam mengorganisasikan pengalaman belajar siswa untuk mencapai tujuan pembelajaran. Model pembelajaran digunakan oleh guru sebagai pedoman dalam melaksanakan proses pembelajaran.

Menurut Shoimin (2014) cooperative learning adalah kegiatan pembelajaran dengan cara berkelompok untuk bekerja sama saling membantu mengonstruksi konsep dan menyelesaikan persoalan. Menurut Slavin dalam Taniredja (2011) Cooperative Learning adalah suatu model pembelajaran di mana dalam sistem belajar dan bekerja dalam kelompok-kelompok kecil yang berjumlah 4-6 orang secara kolaboratif sehingga dapat merangsang peserta didik lebih bergairah dalam belajar.

Bern dan Erickson dalam Komalasari (2015) mengemukakan bahwa cooperative learning merupakan strategi pembelajaran yang mengorganisir pembelajaran dengan menggunakan kelompok belajar kecil dimana peserta didik bekerja sama untuk mencapai tujuan pembelajaran.

Berdasarkan pengertian di kemukakan sebelumnya, peneliti menyimpulkan bahwa cooperative learning merupakan suatu model pembelajaran dimana peserta didik belajar dan bekerja dalam kelompok-kelompok kecil secara kolaboratif yang anggotanya terdiri dari 2 sampai 6 orang, dengan struktur kelompoknya yang bersifat heterogen

Model pembelajaran Course Review Horay merupakan salah satu pembelajaran kooperatif, yaitu kegiatan belajar megajar dengan cara pengelompokan peserta didik kedalam kelompok-kelompok kecil (Shoimin, 2014). Model pembelajaran Course Review Horay merupakan model pembelajaran yang dapat menciptakan suasana kelas menjadi meriah dan menyenangkan karena setiap peserta didik yang dapat menjawab benar diwajibkan berteriak horee!! atau yel-yel lainnya yang disukai (Huda, 2014)

Imran menyatakan bahwa model pembelajaran Course Review Horay merupakan suatu model pembelajaran dengan pengujian pemahaman menggunakan kotak-kotak yang diisi dengan nomor untuk menuliskan jawabannya, yang paling dulu mendapatkan tanda benar vertikal atau horizontal, atau diagonal langsung berteriak "horee!!" Menurut Aqib model pembelajaran Course Review Horay adalah suatu metode pembelajaran dimana guru memberikan kesempatan peserta didik untuk tanya jawab secara individu dengan menyenangkan karena setiap peserta didik yang dapat menjawab dengan benar dapat berteriak horee!! (dalam Gopur, 2017). Selain dapat meningkatkan pemahaman peserta didik pembelajaran ini pun dapat meningkatkan motivasi dan hasil belajar. Course Review Horay juga membuat peserta didik menjadi menjadi aktif dalam pembelajaran.

Berdasarkan pendapat para ahli di atas, dapat disimpulkan bahwa model cooperative learning tipe Course Review Hora merupakan salah satu model pembelajaran dimana kegiatan belajar mengajar dilakukan dengan cara mengelompokkan peserta didik ke dalam kelompok-kelompok kecil

Adapun kelebihan model pembelajaran Course Review Horay (Gopur, 2017) adalah sebagai berikut: (1) Pembelajaran lebih menarik, Artinya, dengan menggunakan model Course Review Horay peserta didik akan lebih bersemangat dalam menerima materi yang akan disampaikan oleh guru karena banyak diselingi dengan games ataupun simulasi lainnya; (2.) Mendorong peserta didik untuk dapat terjun kedalam situasi pembelajaran, Artinya, peserta didik diajak ikut serta dalam melakukan suatu games atau simulasi yang diberikan guru kepada peserta didiknya yang berkaitan dengan materi yang akan disampaikan guru; (3.) Pembelajaran tidak monoton karena diselingi dengan hiburan atau game, dengan begitu peserta didik tidak akan merasakan jenuh yang bisa menjadikannya tidak berkonsentrasi terhadap apa yang dijelaskan oleh guru; (4.) Siswa lebih semangat belajar karena suasana belajar lebih menyenangkan, Artinya, kebanyakan dari peserta didik mudah merasakan jenuh apabila metode yang digunakan oleh guru adalah metode ceramah. Oleh karena itu, dengan menggunakan model pembelajaran Course Review Horay mampu membangkitkan semangat belajar terutama anak Sekolah Dasar yang notabene masih ingin bermain-main; dan (5.) Adanya komunikasi dua arah, Artinya, peserta didik dengan guru akan mampu berkomunikasi dengan baik, dapat melatih peserta didik agar dapat berbicara secara kritis, kreatif dan inofatif. Sehingga tidak akan menutup kemungkinan bahwa akan semakin banyak terjadi interaksi diantara guru dan peserta didik.

Kelebihan model pembelajaran Course Review Horay Shoimin, (2014) antara lain: (a) menarik sehingga mendorong peserta didik terlibat di dalamnya; (b) tidak monoton karena diselingi sedikit hiburan sehingga suasana tidak menegangkan; (c) peserta didik lebih semangat belajar; dan (d) melatih kerja sama. Adapun kekurangan Model Pembelajaran Course Review Horay adalah sebagai berikut: (a) peserta didik aktif dan peserta didik yang tidak aktif nilai disamakan. Artinya, guru hanya akan menilai kelompok yang banyak mengatakan horee!!. Oleh karena itu, nilai yang diberikan guru dalam satu kelompok tersebut sama tanpa bisa membedakan mana peserta didik yang aktif dan yang tidak aktif; dan (b) adanya peluang untuk berlaku curang. Artinya, guru tidak akan dapat mengontrol peserta didik dengan baik apakah ia menyontek ataupun tidak. Guru akan memperhatikan perkelompok yang menjawab horee!! sehingga peluang adanya kecurangan.

Motivasi erat kaitannya dengan sikap belajar. Jika sikap peserta didik terhadap belajar positif, maka ia akan termotivasi atau terpacu untuk belajar. Motivasi adalah aspek yang sangat penting untuk membelajarkan peserta didik. Tanpa adanya motivasi, tidak mungkin peserta didik memiliki kemauan untuk belajar. Oleh karena itu, membangkitkan motivasi merupakan salah satu peran dan tugas guru dalam proses pembelajaran. Menurut Rusman (2016) motivasi dapat diartikan sebagai dorongan yang memungkinkan peserta didik untuk bertindak atau melakukan sesuatu. Menurut Donald dalam Kompri (2016: 229) yang mengatakan bahwa motivasi adalah suatu perubahan energi di dalam pribadi seseorang yang ditandai dengan timbulnya afektif (perasaan) dan reaksi untuk mencapai tujuan. 
Motivasi belajar pada hakikatnya merupakan merupakan kekuatan mental yang mendorong terjadinya proses belajar pada diri peserta didik (Winataputra, 2005). Motivasi belajar adalah keseluruhan daya penggerak dalam diri peserta didik yang menimbulkan kegiatan belajar, yang menjamin kelangsungan dari kegiatan belajar dan memberikan arah pada kegiatan belajar, sehingga tujuan yang dikehendaki oleh subyek belajar itu dapat tercapai (Sudirman dalam Zakky, 2018).

Menurut Sudjana (2008), hasil belajar adalah kemampun yang dimiliki peserta didik setelah ia menerima pengalaman belajarnya. Menurut Suprijono (2013), hasil belajar adalah perubahan perilaku secara keseluruhan bukan hanya salah satu aspek potensi kemanusiaan saja.

Sementara itu, Bloom dalam Solihatin (2013) membagi hasil belajar kedalam tiga ranah, yaitu kognitif, afektif dan psikomotor. Hasil belajar adalah hasil dari suatu kegiatan yang telah dikerjakan, diciptakan, baik secara individual maupun kelompok, sebagai hasil dari kegiatan belajar (Djamarah, 2008).

Berdasarkan penjelasan hasil belajar yang telah diurai, maka dapat diambil kesimpulan bahwa hasil belajar merupakan suatu perolehan yang didapat dari akibat dilakukannya suatu aktivitas yang mengakibatkan perubahan dalam diri individu.

\section{Metode Penelitian}

Jenis penelitian yang peneliti lakukan adalah penelitian eksperimen. Penelitian dengan pendekatan eksperimen adalah suatu penelitian yang berusaha mencari pengaruh variabel tertentu terhadap variabel yang lain dalam kondisi yang terkontrol secara ketat (Riduwan, 2018). Penelitian eksperimen adalah metode penelitian yang digunakan untuk mencari pengaruh perlakuan tertentu. Dalam analisis data guna menguji hipotesis yang telah ditetapkan menggunakan statistik karena bersifat kuantitatif data penelitiannya berupa angka-angka (Sugiono, 2013). Penelitian eksperimen dengan pendekatan kuantitatif digunakan untuk mengetahui peningkatan motivasi dan hasil belajar Tematik peserta didik kelas $\mathrm{V}$ melalui model pembelajaran course review horay di SD Inpres Bakung II Kota Makassar.

Jenis penelitian eksperimen yang digunakan adalah Quasi Experimental Design. Bentuk desain ekperimen ini mempunyai kelompok kontrol, tetapi tidak dapat berfungsi sepenuhnya untuk mengontrol variabel-variabel luar yang mempengaruhi pelaksanaan eksperimen (Sugiono, 2013). Desain eksperimen yang digunakan dalam penelitian ini adalah Non equivalent Control Group Design. rancangan ini tidak jauh berbeda dengan pretest-postest control group design. Penelitian akan dilaksanakan di SD Inpres Bakung II Kota Makassar, J1. Perintis Kemerdekaan Km 18 Kompleks Bumi Permata Sudiang I (BPS I). Populasi dalam penelitian ini adalah peserta didik SD Inpres Bakung II Kota Makassar dengan alamat Jl. Perintis Kemerdekaan km 18 Kompleks Bumi Permata Sudiang I (BPS 1) Kota Makassar, pada semester genap tahun pelajaran 2018/2019 yang berjumlah 409 peserta didik dalam 12 kelas.

Dalam penelitian ini angket digunakan untuk memperoleh data motivasi belajar peserta didik. Bentuk angket yang digunakan dalam penelitian ini adalah instrumen yang berupa daftar pernyataan tertulis yang terdiri dari 30. Pedoman angket yang digunakan peneliti berdasarkan indikator-indikator motivasi belajar. Indikator adanya motivasi belajar Tematik pada peserta didik yaitu: (1) adanya hasrat dan keinginan untuk berhasil; (2) adanya dorongan dan kebutuhan untuk belajar; (3) adanya harapan dan cita-cita masa depan; (4) adanya penghargaan dalam belajar; (5) adanya kegiatan menarik dalam belajar; dan (6) adanya lingkungan belajar yang kondusif sehingga memungkinkan peserta didik dapat belajar dengan baik. Data hasil belajar diambil setelah pembelajaran atau pemberian perlakuan selesai. Penyusunan instrumen disesuaikan dengan hasil belajar kognitif yang telah ditentukan pada kajian pustaka hasil belajar. Instrumen ini berbentuk tes objektif berupa soal pilihan ganda, isian, dan uraian. Uji hipotesis yang digunakan pada penelitian ini adalah uji nonparametrik dengan teknik uji Wilcoxon. Uji ini bertujuan untuk melihat perbedaan yang skor sebelum dan sesudah perlakuan.

\section{Hasil dan Pembahasan}

Dalam penelitian ini, peneliti memperoleh data dari hasil pre-test dan post-test yang dilakukan pada kelas eksperimen dan kelas kontrol. Pre-test merupakan tes kemampuan yang diberikan kepada peserta didik sebelum diberi perlakuan, sedangkan post-test dilakukan setelah peserta didik mendapatkan perlakuan. Kedua tes ini berfungsi untuk mengukur sampai mana keefektifan program pembelajaran. Sebelum melakukan pengambilan data, peneliti melakukan uji coba terhadap instrumen soal yang akan digunakan sebagai soal pre-test dan post-test. Untuk data hasil belajar dari 20 soal uji coba instrumen terdapat 3 soal yang gugur yaitu item nomor 5, 14, dan 15. Item ini gugr karena $r$ hitung lebih kecil daripada $r$ tabel pada taraf signifikan 5\%. Dari perhitungan yang dilakukan juga didapatkan nilai r sebesar 0,56. Maka dapat disimpulkan instrumen tes motivasi belajar reliabel dengan kriteria tinggi.

Untuk data motivasi belajar dari 30 soal uji coba instrumen terdapat 28 soal yang gugur karena $\mathrm{r}$ hitung lebih kecil daripada $r$ tabel pada taraf signifikan 5\%. Dari perhitungan yang dilakukan juga didapatkan nilai $r$ sebesar 0,60. Maka dapat disimpulkan instrumen tes motivasi belajar reliabel dengan kriteria tinggi.

Selanjutnya, peneliti mengambil data hasil awal dengan menggunakan pre-test pada kelas eksperimen dan kelas kontrol. Kemudian diberi perlakuan, dimana kelas eksperimen menggunakan metode course riview horay. Setelah kedua kelas tersebut diberi perlakuan, selanjutnya diberikan post-test kepada kedua kelas tersebut. Hal ini dilakukan untuk mengetahui kemampuan akhir peserta didik setelah perlakuan. 


\begin{tabular}{|c|c|c|c|c|}
\hline & \multicolumn{4}{|c|}{ Tabel 1 Hasil Uji Hipotesis } \\
\hline & $\begin{array}{c}\text { Pre-post test } \text { Motivasi } \\
\text { belajar kelompok } \\
\text { Kontrol }\end{array}$ & $\begin{array}{c}\text { Pre-post test Motivasi } \\
\text { Belajar kelompok Kontrol }\end{array}$ & $\begin{array}{c}\text { Pre-post test Hasil } \\
\text { belajar kelompok } \\
\text { Eksperimen }\end{array}$ & $\begin{array}{l}\text { Pre-post test Hasil belajar } \\
\text { kelompok Kontrol }\end{array}$ \\
\hline $\mathrm{Z}$ & $-5,514^{b}$ & $-1,018^{b}$ & $-5,519^{b}$ & $-4,078^{b}$ \\
\hline $\begin{array}{l}\text { Asymp. Sig. (2- } \\
\text { tailed) }\end{array}$ & ,000 & ,309 &, 000 & ,000 \\
\hline
\end{tabular}

Sumber: Analisa Data, 2020

Uji Wilcoxon pre-test dan post-test kelas eksperimen bertujuan untuk mengetahui ada tidaknya peningkatan skor hasil belajar. Kesimpulan penelitian dinyatakan signifikan apabila $\mathrm{t}$ hitung $>\mathrm{t}$ tabel pada taraf signifikansi $5 \%$ dan nilai $\mathrm{p}<0,05$. dari hasil penelitian didapatkan rata-rata nilai pre-test kelas eksperimen sebesar 16,05 dan rata-rata nilai post-test sebesar 35,08 yang berarti terjadi peningkatan skor hasil belajar sebesar 19,03.

Uji Wilcoxon pre-test dan post-test kelas kontrol bertujuan untuk mengetahui ada tidaknya peningkatan skor. Kesimpulan penelitian dinyatakan signifikan apabila $t$ hitung $>\mathrm{t}$ tabel pada taraf signifikansi $5 \%$ dan nilai $\mathrm{p}<0,05$. hasil penelitian didapatkan rata-rata nilai pre-test kelas kontrol sebesar 14,55 dan rata-rata nilai post-test sebesar 17,97 yang berarti terjadi penigkatan skor hasil belajar sebesar 3,42 namun belum memperlihatkan hasil yang memuaskan.

Uji Wilcoxon pre-test dan post-test kelas eksperimen bertujuan untuk mengetahui ada tidaknya peningkatan skor. Kesimpulan penelitian dinyatakan signifikan apabila $t$ hitung $>\mathrm{t}$ tabel pada taraf signifikansi 5\% dan nilai $\mathrm{p}<0,05$

Berdasarkan tabel di atas dapat dinyatakan bahwa terdapat pengaruh yang signifikan antara nilai pre-test dengan nilai post-test yang dibuktikan dengan nilai $\mathrm{p}=0,000<0,05$, sedangkan dari hasil penelitian didapatkan rata-rata nilai pre-test kelas eksperimen sebesar 59,50 dan rata-rata nilai post-test sebesar 146,67 yang berarti terjadi penigkatan skor hasil belajar sebesar 87,17

Uji Wilcoxon pre-test dan post-test kelas kontrol bertujuan untuk mengetahui ada tidaknya peningkatan skor. Kesimpulan penelitian dinyatakan signifikan apabila $\mathrm{t}$ hitung $>\mathrm{t}$ tabel pada taraf signifikansi 5\% dan nilai $\mathrm{p}<0,05$

Berdasarkan tabel di atas dapat dinyatakan bahwa tidak terdapat pengaruh yang signifikan antara nilai pre-test dengan nilai post-test yang dibuktikan dengan nilai $\mathrm{p}=0,309>0,05$, sedangkan dari hasil penelitian didapatkan rata-rata nilai pretest kelas eksperimen sebesar 59,37 dan rata-rata nilai post-test sebesar 60,05 yang berarti terjadi peningkatan skor motivasi belajar sebesar 0,68 poin, skor ini menunjukkan ada perbedaan rata-rata nilai, namun tidak signifikan.

\section{Motivasi Belajar}

Dari pertemuan satu, dua, dan tiga peneliti dapat melihat bahwa motivasi belajar peserta didik sangat tinggi dengan penerapan model pembelajaran Course Review Horay. Sesuai pendapat Shoimin, (2014) kelebihan model pembelajaran Course Review Horay antara lain: (a) menarik sehingga mendorong peserta didik terlibat di dalamnya; (b) tidak monoton karena diselingi sedikit hiburan sehingga suasana tidak menegangkan; (c) peserta didik lebih semangat belajar; dan (d) melatih kerja sama. Model pembelajaran Course Review Horay sangat sesuai di gunakan pada pembelajaran tematik sebagai mana pendapat yang dikemukakan oleh Prastowo (2019) bahwa Pembelajaran tematik menawarkan model-model pembelajaran yang menjadikan aktivitas pembelajaran itu relevan dan penuh makna bagi peserta didik, baik aktivitas formal maupun informal, meliputi pembelajaran inquiry secara aktif sampai dengan penyerapan pengetahuan dan fakta secara pasif, dengan memberdayakan pengetahuan dan pengalaman peserta didik untuk membantunya mengerti dan memahami dunia kehidupannya. Dengan model pembelajaran course Review Horay, maka peserta didik akan termotivasi mengikuti pembelajaran dari awal sampai akhir kegiatan sehingga tujuan pembelajaran dapat tercapai.

Pada pemberian post-test peserta didik bersemangat mejawab pertanyaan dan dengan percaya diri. Peserta didik mampu menjawab pertanyaan dengan baik. Terbukti bahwa nilai peserta didik tinggi. Hal ini membuktikan bahwa penerapan model pembelajaran Course Review Horay pada pembelajaran tematik dapat meningkatkan hasil belajar peserta didik. Hasil belajar merupakan suatu perolehan yang didapat dari akibat dilakukannya suatu aktivitas yang mengakibatkan perubahan dalam diri individu.

Berdasarkan hasil penelitian didapatkan rata-rata nilai pre-test kelas eksperimen sebesar 59.50 dan rata-rata nilai posttest sebesar 146.67 yang berarti terjadi peningkatan skor motivasi belajar sebesar 87.17. Peningkatan motivasi belajar yang terjadi pada kelas eksperimen dalam hal ini kelas V-A SD Inpres Bakung II Kota Makassar sejalan dengan pendapat para ahli. Salah satu diantaranya menurut Donald dalam kompri (2016: 229) yang mengatakan bahwa motivasi adalah suatu perubahan energi di dalam pribadi seseorang yang ditandai dengan timbulnya afektif (perasaan) dan reaksi untuk mencapai tujuan. Model pembelajaran Course Review Horay merupakan model pembelajaran yang mampu menciptakan suasana kelas menjadi meriah dan menyenangkan yang tentunya mampu meningkatkan motivasi peserta didik dan sangat mendukung keberhasilan pembelajaran tematik. Salah satu karakteristik pembelajaran tematik menurut Rusman (2015) adalah menggunakan prinsip belajar sambil bermain dan menyenangkan, dalam proses pembelajaran tematik tidak menjemukan/membosankan bahkan dalam suasana bermain yang menyenangkan mereka dapat memperoleh pengetahuan baru secara utuh yang sangat bermakna khususya di kelas V-A SD Inpres Bakung II Kota Makassar.

Dengan penerapan peranan guru seperti penjelasan sebelumnya, maka guru akan mampu menempatkan diri dalam lingkungan peserta didik secara tepat. Pada gilirannya guru akan mampu pula menggunakan teknik, motivasi secara tepat, baik dalam suasana kelompok maupun dalam suasana individual. Model pembelajaran Course Review Horay merupakan salah satu cara yang dapat di lakukan oleh guru untuk meningkatkan motivasi belajar peserta didik. 
Penelitian serupa dilakukan oleh Meirza Nanda Faradita pada peserta didik jenjang pendidikan Sekolah Dasar (SD), dalam penelitian tersebut sejalan dengan yang peneliti lakukan bahwa model pembelajaran Course Review Horay efektif dalam meningkatkan motivasi belajar serta memiliki pengaruh yang signifikan terhadap motivasi belajar peserta didik.

\section{Hasil Belajar}

Berdasarkan hasil penelitian didapatkan rata-rata nilai pre-test kelas kontrol sebesar 14,55 dan rata-rata nilai post-test kelas kontrol sebesar sebesar 17,97 yang berarti terjadi peningkatan skor hasil belajar sebesar 3,42. Pada dasarnya, kelas kontrol juga mengalami peningkatan hasil belajar namun belum memperlihatkan hasil yang memuaskan karena hasil belajar peserta didik masih rendah.

Berdasarkan uji t post-test diketahui rata-rata hasil belajar kelas eksperimen sebesar 35.08 dan rata-rata hasil belajar kelas kontrol sebesar 17.97 sehingga didapatkan rata-rata hasil belajar kelas eksperimen lebih besar dari kelas kontrol. Yang berarti bahwa ada perbedaan hasil belajar kelas eksperimen dan kelas kontrol.

Dari pemaparan hasil belajar kelas eksperimen dan kelas kontrol, dapat peneliti simpulkan bahwa ada pengaruh model pembelajaran Course Review Horay terhadap hasil belajar peserta didik kelas V SD Inpres Bakung II Kota Makassar. Hasil belajar peserta didik dipengaruhi oleh kemampuan peserta didik dan kualitas pengajaran. Kualitas pengajaran yang dimaksud adalah profesionalitas dan keahlian yang dimiliki oleh guru. Artinya kemampuan dasar guru baik kognitif (pengetahuan), afektif (sikap), dan psikomotorik (keterampilan) sangat berpengaruh dalam menentukan hasil belajar peserta didik. oleh karenanya seorang guru sudah seharusnya kaya akan variasi dan model pembelajaran sehingga hasil belajar peserta didik mejadi lebih baik.

Penelitian lain dilakukan oleh Ul Yani pada jenjang pendidikan Sekolah Dasar (SD) menyimpulkan bahwa ada pengaruh model pembelajaran cooperative learning tipe Course Review Horay untuk meningkatkan hasil belajar peserta didik dengan kategori sangat baik. Begitu pula penelitian yang dilakukan oleh Lorensius Tomi dan Desy Ana Heryyanti pada jenjang Sekolah Dasar (SD), serta penelitian yang dilakukan oleh Chotim Alfa Ni Amah pada jenjang pendidikan Sekolah Menengah Pertama (SMP) yang juga menyimpulkan bahwa ada pengaruh model pembelajaran Course Review Horay terhadap hasil belajar peserta didik pada kelas eksperimen lebih meningkat jika dibandingkan pada kelas control.

\section{Kesimpulan dan Saran}

Hasil penelitian dapat disimpulkan bahwa motivasi belajar peserta didik dengan menggunakan model pembelajaran Course Review Horay sangat tinggi. Peserta didik lebih bersemangat, dapat menciptakan suasana kelas menjadi lebih meriah dan menyenangkan karena setiap peserta didik yang dapat menjawab benar diwajibkan berteriak horee!! Atau yel-yel lain yang di sukai. Gambaran hasil belajar peserta didik dengan menggunakan model pembelajaran Course Review Horay tinggi sehingga terjadi peningkatan hasil belajar. Guru sebagai pendidik diharapkan mampu menciptakan suasana kelas yang menyenangkan sehingga peserta didik termotivasi untuk mengikuti proses belajar mengajar dengan baik dan tidak merasa bosan. Salah satu cara yang bisa dilakukan adalah dengan penerapan model pembelajaran Course Review Horay. Guru diharapkan mampu menguasai kelas dalam penerapan model pembelajaran Course Review Horay sehingga proses belajar mengajar dapat berjalan dengan baik dan tujuan pembelajaran dapat tercapai.

\section{Daftar Pustaka}

Asdar. 2018. Metode Penelitian Pendidikan. Bogor: Azkiya Publishing

Depdiknas .2003. Undang-undang RI No.20 tahun 2003.tentang sistem pendidikan nasional.

Djamarah, Syaiful Bahri. 2008. Psikologi Belajar. Jakarta: Rineka Cipta.

Faturrohman, Muhammad. 2017. Model-Model Pembelajaran Inovatif. Jogyakarta: Ar-Ruzz Media.

Gopur, Abdul. Model Pembelajaran Course Review Horay (CRH). Tersedia:

http://abdulgopuroke. Blogspot.com/2017.03/ Model Pembelajaran Course Review Horay (CRH). Diakses tgl 9 Maret 2019.

Huda, Miftahul. 2014. Model-Model Pengajaran dan Pembelajaran. Jogyakarta: Pustaka Pelajar.

Jainuddin, J. (2019). Peningkatan Hasil Belajar Matematika Melalui Latihan Menyelesaikan Soal Secara Sistematis Pada Siswa Kelas XI. IPA1 Sma Negeri 2 Sungguminasa. Klasikal: Journal Of Education, Language Teaching And Science, 1(3), 44-52.

Jainuddin, J., \& Sirajuddin, S. (2020). Pengaruh Minat dan Kedisiplinan Siswa dengan Gaya Kognitif Field Indefendent terhadap Hasil Belajar Matematika Siswa SMK Farmasi Yamasi Makassar. Delta-Pi: Jurnal Matematika dan Pendidikan Matematika, 9(2).

Komalasari, Kokom. 2015. Pembelajaran Kontekstual Konsep dan Aplikasi. Bandung: PT Refika Aditama.

Kompri. 2016. Motivasi Pembelajaran Perspektif Guru dan Siswa. Bandung: Rosda.

Prastowo, Andi. 2019. Analisis Pembelajaran Tematik Terpadu. Jakarta: Prenamedia Group (Divisi Kencana).

Riduwan. 2018. Metode dan Teknik Menyusun Tesis. Bandung: Alfabeta.

Rusman. 2016. Model- Model Pembelajaran. Jakarta: PT Rajagrafindo Persada.

Shoimin, Aris. 2014. 68 Model Pembelajaran Inovatif Dalam Kurikulum 2013. Yogyakarta: Ar Ruzz Media.

Sudjana, Nana.2008. Penilaian Hasil Proses Belajar Mengajar. Bandung: Remaja Rosdakarya.

Suprijono, Agus. 2013. Cooperative Learning. Surabaya: Pustaka Pelajar.

Taniredja, Tukiran, dkk. 2011. Model-Model Pembelajaran Inovatif dan Efektif. Bandung: Alfabeta.

Trianto. 2015. Model-Model Pembelajaran Terpadu. Jakarta: Bumi Aksara. 
Tammeng, Rahman. 2012. Meningkatkan Hasil Belajar IPS Melalui penerapan Model Pembelajaran Mind Mapping pada peserta didik kelas V SDN inpres 131 Tobonggae Kecamatan Camba Kabupaten Maros. Skripsi. Tidak diterbitkan. Makassar: FKIP Unismu Makassar.

Tiro, Muhammad Arif. Ahmar, Anshari, Saleh. 2014. Penelitian Eksperimen: merancang, Melaksakan, dan Melaporkan Makassar. Andira Publisher.

Trianto. 2008. Mendesain Pembelajaran CTL (Contextual Teaching and Learning (CTL)) Dikelas. Jakarta. Cerdas Pustaka. Undang-undang No. 20 Tahun 2003 tentang Sistem Pendidikan Nasional Sikdiknas

Yaba. 2009. Materi Pendidikan IPS di SD. Makassar. Universitas Negeri Makassar. 